\title{
The obesity epidemic: from the environment to epigenetics - not simply a response to dietary manipulation in a thermoneutral environment
}

\author{
Michael E. Symonds*, Sylvain Sebert and Helen Budge \\ Early Life Nutrition Research Unit, Academic Division of Child Health, Nottingham Respiratory Medicine Biomedical Research Unit, School of Clinical Sciences, \\ University Hospital, Nottingham, UK
}

Edited by:

Zdenka Pausova, The Hospital for Sick Children, Canada

\section{Reviewed by:}

Kieron Bernard Rooney, University of Sydney, Australia

Michael Carey Satterfield, Texas A\&M

University, USA

*Correspondence:

Michael E. Symonds, Academic Division of Child Health, School of Clinical Sciences, University Hospital, Nottingham NG7 2UH, UK.

e-mail: michael.symonds@nottingham .ac.uk
The prevalence of obesity continues to increase particularly in developed countries. To establish the primary mechanisms involved, relevant animal models which track the developmental pathway to obesity are required. This need is emphasized by the substantial rise in the number of overweight and obese children, of which a majority will remain obese through adulthood. The past half century has been accompanied with unprecedented transitions in our lifestyle. Each of these changes substantially contributes to enhancing our capacity to store energy into adipose tissues. The complex etiology of adiposity is critical as a majority of models investigating obesity utilize a simplistic high-fat/low-carbohydrate diet, fed over a short time period to comparatively young inbred animals maintained in fixed environment. The natural history of obesity is much more complex involving many other mechanisms and this type of challenge may not be the optimal experimental intervention. Such processes include changes in adipose tissue composition with time and the transition from brown to white adipose tissue. Brown adipose tissue, due its unique ability to rapidly produce large amounts of heat could have a pivotal role in energy balance and is under epigenetic regulation mediated by the histone H3k9-specific demethylase Jhdma2a. Furthermore, day length has a potential role in determining endocrine and metabolic responses in brown fat. The potential to utilize novel models and interventions across a range of animal species in adipose tissue development may finally start to yield sustainable strategies by which excess fat mass can, at last, be avoided in humans.

Keywords: obesity, development, brown adipose tissue, photoperiod, FTO

\section{INTRODUCTION}

Over the past decades there have been a substantial number of publications indicating that the way an individual grows and develops early in life directly impacts upon their cardio-metabolic health in later life (McMillen and Robinson, 2005; Symonds et al., 2009). At the same time, some authors have been skeptical of this relationship emphasizing that current adult lifestyle is perhaps more important (Bray et al., 2004; Slyper, 2004). Coincident with these arguments has been the global increase in the incidence of adult and, crucially, of childhood obesity (Flegal et al., 2010; Gaziano, 2010). The extent to which the substantial changes in contemporary lifestyles have contributed to the current obesity epidemic similarly remains controversial and several authors have indicated that there may be other plausible explanations other than excess food intake and/or reduced physical activity (Keith et al., 2006; McAllister et al., 2009). As such, although young sedentary rodents which are overfed for a relatively short period of time and maintained within a constant thermoneutral environment, may be considered as an acceptable model for the study of obesity in humans, treatments which may work to overcome obesity in such models could well be inappropriate in active subjects irrespective of body weight (Martin et al., 2010).
There are several major challenges to our ability to determine the primary causes and consequences of obesity and these include the difficulty in accurately recording dietary intake simultaneously with measurements of physical activity, energy expenditure and environmental changes in humans (Johnson et al., 2011). At the same time, a large number of animal studies, primarily in rodents, have adopted the rather simplistic view that increasing fat intake by between 5 - and 10 -fold, whilst reducing the intake of other macronutrients (particularly carbohydrate; Ainge et al., 2010; Table 1), over a relatively short time period of a few weeks mimics the type of metabolic adaptations and increased fat mass which often take several years to occur in humans. Furthermore, these animals are usually maintained within a constant thermoneutral environment and in isolation of other animals, which they would rarely encounter in the wild. In humans, although even a doubling of fat intake has a marked impact on food intake and energy balance (Schrauwen and Westerterp, 2000), this type of change has not been observed in human populations in recent times (Garriguet, 2007). In addition, genome-wide association studies on very large cohorts are providing more detailed insights into individual, or combinations of, genotypes which contribute to an increased body mass index (Bauer et al., 2009; Lindgren et al., 
Table 1 | Comparison of the macronutrient composition of a standard adult human diet with those used in nutritional studies involving primates and rodents.

\begin{tabular}{|c|c|c|c|c|c|c|c|}
\hline \multirow[t]{2}{*}{ Species } & \multicolumn{3}{|c|}{ Control (or normal) diet (\%) } & \multicolumn{3}{|c|}{ High-fat:low-carbohydrate diet (\%) } & \multirow[t]{2}{*}{ Reference } \\
\hline & Protein & Carbohydrate & Fat & Protein & Carbohydrate & Fat & \\
\hline Primate & 18 & 72 & 11 & 16 & 31 & 52 & McCurdy et al. (2009) \\
\hline Rodent & 21 & 71 & 6 & 15 & 55 & 15 & Ainge et al. (2010) \\
\hline
\end{tabular}

2009; den Hoed et al., 2010; Li et al., 2010). These appear to impact on an individual's susceptibility to obesity within an obesogenic environment rather than being a major cause.

Such findings are not unexpected given the rapid increase in the occurrence of obesity in both children and adults over the past 15 years (e.g., Figure 1). However, determining the different pathways that may be involved still requires an approach which combines detailed, imaginative animal studies with intensive in vivo measurements on individuals of known genotype and body fat distribution whose dietary and activity status is available for scrutiny across a range of environmental and nutritional challenges. In the present review, we will consider some of the main limitations to our understanding of the causes of obesity, particularly from a developmental view-point, and whether the current vogue for seeking epigenetic explanations for this process is really supported by the science.

\section{LIMITATIONS OF HISTORICAL AND PROSPECTIVE STUDIES IN HUMAN POPULATIONS FOR EXPLAINING THE CAUSES AND CONSEOUENCES OF OBESITY IN CONTEMPORARY SOCIETY}

Since the end of the Second World War, there has been a dramatic change in our lifestyles and many of the identified factors acting alone could be anticipated to promote obesity. The "step-wise" adaptations in lifestyles within the developed world have coincided with "rural flight," a substantial rise in the use of mechanical transportation (Juneau and Potvin, 2010), a reduction in manual

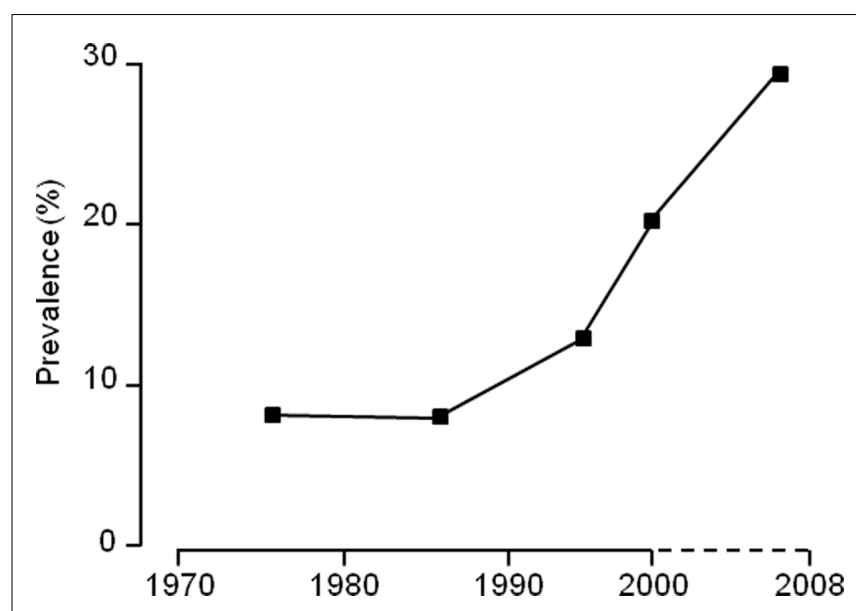

FIGURE 1 | The change in incidence of overweight and obese children in the United Kingdom between 1980 and 2009. labor and altered working patterns with more shift work adding to disease risk (Puttonen et al., 2010; Szosland, 2011). These, in turn, have a variety of social and health related effects (Ramsden, 2009) even impacting upon reproductive success and birth weight (Masi et al., 2007).

Although in contemporary society in the developed world less disposable income is spent on food and the majority of food purchasing takes place in supermarkets (Pettinger et al., 2008), the extent to which the amount of processed food consumed has changed remains controversial. At the same time, there has been a rise in the viewing of an expanding number of television channels, the majority of which are highly dependent on food and soft drink advertising revenue (Wells et al., 2008; Charreire et al., 2011). Nevertheless, whether there have been consistent increases in total food or specific nutrient intakes over the past 20-30 years is unclear. There is not strong evidence of a significant increase in food consumption with both intake of both total energy and fat decreasing in many age groups (Garriguet, 2007; Stahl et al., 2009). These secular trends are dependent, in part upon, gender (Popkin et al., 1989), socioeconomic class (Hulshof et al., 2003) and the industrial status of a country (Kearney, 2010). It should also be recognized that accurate data of food intakes can be very challenging when it is largely based on information gathered from questionnaires. Importantly, to date, the relative contributions of diet and exercise in the etiology of obesity remain inconclusive (Bleich et al., 2011).

Further changes in living environments have included the increased use of central heating, air conditioning and artificial lighting (Keith et al., 2006) in combination with global changes in temperature and carbon dioxide concentrations which have accompanied climate change and are predicted to further accelerate (Walker, 2006; Hansen et al., 2007). In the face of these challenges, there is now evidence across a large spectrum of species that mature body weight has increased over the past two decades (Klimentidis et al., 2011), although it remains to be established whether this equates with greater fat mass. There is also a social divergence in the maternal age at first pregnancy. Teenage pregnancies occur in a significant proportion of girls from lower socioeconomic classes with adverse early life experiences (Harden et al., 2009). In marked contrast, women who are both better educated and more affluent tend to delay their first pregnancy until much later in life (Tromp et al., 2011). Dietary intakes of these groups of women are different (Knudsen et al., 2008) as is their incidence of breast feeding. Some authors have considered that the majority of established health benefits to the offspring are a reflection of social class, together with maternal education (Kelly 
and Watt, 2005; Skafida, 2009), rather than the result of maternal milk as a primary source of nutrition. As families have become smaller, the amount of investment in each offspring may further promote excess fat mass (Liefbroer, 2009).

In view of the major changes in societal influences over the past few decades, it is prudent to place much less emphasis on findings from cohorts of children born at times of modest rates of childhood obesity when looking for contemporary explanations for the rise in adult and childhood obesity over the last 15 years (Figure 1; Reilly and Kelly, 2010).

\section{CURRENT ANIMAL MODELS USED TO EXAMINE THE CONSEQUENCES AND TREATMENT OF OBESITY}

In the context of a lack of convincing evidence that total fat intake alone has changed substantially in contemporary populations over the past 20 years, there are very many rodent and non-human primate models of obesity which simply increase the fat content of the diet by between 5- and 10-fold whilst protein, and to a much greater extent carbohydrate, content is substantially reduced (Table 1). This may mean that although the diets appear broadly comparable to human diets in the developed world in terms of gross macronutrient content, their fat content is more dense. The short-term responses to these diets are likely to be quite different to those which may occur in response to those consumed by humans and it is unlikely that such a dramatic and sustained increase in fat consumption would occur in species with food choice. Although promoting fat intake rapidly enhances fat mass and concomitant changes in its molecular activity, it is perhaps not surprising that some pharmacological interventions which have been successful in rodent studies (e.g., rosiglitazone) appear to have deleterious effects in humans which has resulted in the cessation of their use, at least in Europe (Scheen, 2010).

The primary animal models for investigating obesity remain mice and rats, with the former having the distinct advantage of being open to substantial genetic manipulation. The latter often results in pronounced differences at birth whose significance is usually over-looked. For example, knockout of the uncoupling protein (UCP) 2 gene results in a reduced litter size (Rousset et al., 2003). The translational relevance of the information obtained must be considered with caution as there is now an increasing awareness of the very artificial and constrained environment in which these animals are raised (Martin et al., 2010). In addition, it is becoming increasingly apparent that the gene profile of specialized tissues involved in energy balance, such as brown adipose tissue (BAT), has a very different molecular signature in humans compared with mice (Svensson et al., 2011). The critical role of BAT will be considered in more detail below as there is increasing data demonstrating that BAT activity is reduced in obese humans (Vijgen et al., 2011).

Developmental studies in larger animal models have enabled significant clinical advances such as in the use of glucocorticoids to promote lung maturation in preterm infants (Olson, 1979; Ballard, 1983). However, to date, despite some appreciable benefits (Symonds et al., 2009), they are seldom used in nutritional studies. Nevertheless, it is now possible to undertake genetic manipulations in large mammals with a fascinating model of cystic fibrosis, for example, now established in the pig (Rogers et al., 2008; Meyerholz et al., 2010). One obvious reason for the limited use of these models is their much longer time scale and consequent expense despite the results of studies conducted during early life being of potentially greater relevance.

There is now a clear need to undertake complementary studies across a range of mammalian species, both large and small reared under a variety of environmental conditions and dietary regimes, ideally throughout their life cycle.

\section{ALTERNATIVE DIETARY MODELS OF OBESITY}

In view of the hypothesis that maternal obesity could be an important contributor to increased birth weight and fat mass in the offspring (Sewell et al., 2006; Catalano, 2007) which in turn results in offspring at increased risk of later obesity a number of animal models have attempted to replicate these findings. This has included the more traditional approach of high-fat/lowcarbohydrate or low-protein diets which has quite different outcomes between rodents and non-human primates (Khan et al., 2003; Jones et al., 2009; McCurdy et al., 2009). In mice a highfat/low-carbohydrate diet does not affect maternal body weight but increases near-term fetal, but not placental weight (Jones et al., 2009). Consumption of a high-fat/low-protein diet sufficient to increase maternal body weight by $\sim 10 \%$ in non-human primates has no effect on birth weight or early postnatal growth but does result in a modest increase in total body fat from 3.5 to $5.7 \%$ by 90 days of age, although fat mass then declines by 180 days of age (McCurdy et al., 2009). This species thus differs from both humans and sheep in which substantial fat growth occurs postnatally (Clarke et al., 1997; Budge and Symonds, 2006).

A number of other dietary formulations have also been investigated in which the high-fat has been complemented with increased intake of simple sugars, at the expense of protein and polysaccharides (Kirk et al., 2009) or raised salt and less fiber (Bayol et al., 2007). Neither of these diets appears to have any effect on birth weight but do promote maternal weight gain. Not surprisingly the longer the duration over which this type of diet is consumed the greater the fat mass in the offspring (Bayol et al., 2008). Whilst exposure to a high-fat/high-sugar diet both before, and through pregnancy and lactation increases fat mass at the expense of muscle in the adult offspring irrespective of gender (Samuelsson et al., 2008). These types of responses are very different to those seen when only the father is fed a high-fat/ low-carbohydrate diet in which no effect on body composition is apparently seen in the offspring, although females show modest $\beta$-cell pancreatic dysfunction at 12 weeks of age ( $\mathrm{Ng}$ et al., 2010). It remains to be shown if these symptoms persist, are truly gender specific and ultimately accompanied by enhanced lipid deposition.

In the sheep, increased body mass can be induced by ad libitum feeding over a comparatively short time prior to mating, although this has no subsequent effect on birth weight (Wang et al., 2010). It maybe that the metabolic changes observed in these types of small and large animal models do not really reflect the changes seen in obese women. For example, they would not be expected to show such a remarkable magnitude of hyperinsulinaemia (e.g., a fivefold increase in plasma insulin up to $25 \mu \mathrm{U} / \mathrm{ml}$ ) that is maintained through gestation as reported in obese pregnant sheep (Wang et al., 2010). Indeed, the relative contributions of pre-pregnancy weight 
versus weight gain through gestation remain largely unexplored. Interestingly allowing pregnant sheep to eat ad libitum from midpregnancy increases birth weight but does not have a major effect on maternal fat mass (Budge et al., 2000). Irrespective of these nutritional and related factors it is clear that simply changing maternal diet around the time of conception or during gestation will not provide a simple solution to the potential long-term adverse outcomes of being born to a mother who is consuming too much food (Symonds et al., 2010).

\section{GENDER CAN MAKE A DIFFERENCE}

It is becoming increasingly apparent that litter size, together with gender can result in misleading conclusions in developmental studies (Symonds and Budge, 2009). There are substantial differences in body composition, particularly in fat mass and composition, which are apparent between genders and these occur across a majority of species and can vary with age. In rodents and other species, females reach their mature body weight much earlier than males, who continue to grow and deposit fat for longer (Symonds, 2007). Other gender differences in rodents include an increased retention of BAT with age in females (Pearce et al., 2003 ) in conjunction with increased "drive" to undertake exercise (Cortright et al., 1997). These differences will have substantial consequences for the control of energy balance with different pathways involved in males and females depending on whether a gene is ablated or amplified and following a nutritional, or related, intervention. There is increasing evidence from human clinical studies that women are often protected from the adverse effects of sepsis (Adrie et al., 2007) or obesity (Regitz-Zagrosek et al., 2006), for example, at least until after the menopause (Shaw et al., 2008). As such, with the increasing age of populations across the developed world the need to not only consider gender but also age is likely to become a priority although this clearly increases the costs of any research project.

\section{BROWN ADIPOSE TISSUE AS A TARGET OF WEIGHT PREVENTION}

A potential target tissue in the prevention of obesity, especially in children, is BAT which is primarily located within the supraclavicular region and is uniquely able to rapidly generate heat due to the presence of UCP1 (Cannon and Nedergaard, 2008; Cypess and Kahn, 2010a,b). Heat production by BAT is $300 \mathrm{~W} / \mathrm{g}$ compared to $1 \mathrm{~W} / \mathrm{g}$ in all other tissues (Power, 1989; Symonds et al., 2011). It has, therefore, been calculated that in adult humans only $40-50 \mathrm{~g}$ of BAT would be required for it to be able to contribute to $20 \%$ of daily energy expenditure (Rothwell and Stock, 1979, 1983). This calculation is based on the assumption that BAT would be continually stimulated which is unlikely to be the case even with a severe cold challenge of adults (van Marken Lichtenbelt et al., 2009). The potential role of BAT in body weight regulation has returned to the forefront of obesity related research since its discovery in adult humans 3 years ago (Cypess et al., 2009; van Marken Lichtenbelt et al., 2009; Virtanen et al., 2009; Lee et al., 2010). Its function does appear to be greatly suppressed in obese adults (Vijgen et al., 2011), but whether it can be reactivated in these individuals will become a major challenge. The control of BAT has been extensively investigated in rodents (Cannon and Nedergaard, 2004) and young sheep
(Symonds et al., 2003) but the extent to which these findings are translatable to the human situation remains to be established.

\section{DIURNAL AND PHOTOPERIODIC CHANGES IN METABOLIC CONTROL AND THEIR CONTRIBUTION TO EXCESS FAT MASS}

Rodents exhibit pronounced changes in their activity which impact on metabolic control (Gimble and Floyd, 2009) and are driven, in part, by photoperiod. Thus they are very active in the night and sedentary through the day even when maintained under laboratory conditions (Heldmaier and Steinlechner, 1981). This is especially important when investigating energy balance and the potential role of BAT which is much more active at night than day (Rothwell et al., 1983; Stefanidis et al., 2009). Simply changing day length, therefore, has the potential to cause a pronounced effect on body mass as a consequence of increased activity of the BAT-specific UCP1 (Cannon and Nedergaard, 2004). Interestingly, interventions targeted at manipulating heat production by this tissue appear to only have an effect when the animal is active (Stefanidis et al., 2009). At the same time, increasing the length of time mice are exposed to light means they spend a greater proportion of the day having to consume food under these environmental conditions which can enhance white fat deposition and raise total body weight (Fonken et al., 2010). This is accompanied by a blunting of the normal diurnal variation in plasma corticosterone in a manner not dissimilar to that seen when access to food is limited to a 12-h period of light (Zvonic et al., 2006). Under the latter conditions, overall food intake and body weight remains unaffected despite a resetting of circadian-controlled gene expression patterns in brown and white fat and in the liver (Zvonic et al., 2006).

Nocturnin is one potential factor which has been implicated in the diurnal cycling of mRNAs through regulation of deadenylase and exhibits a 100-fold change in abundance between night and day (Wang et al., 2001). Deletion of this gene reduces physical activity and body temperature in conjunction with an apparent reduction in efficiency of food absorption such that body weight is reduced despite a similar food intake to controls (Green et al., 2007). Effects on gene expression of important metabolic genes such as peroxisome proliferator-activated receptor (PPAR) $\gamma$, sterol regulatory element-binding protein-1c and steroyl-CoA desaturase are only apparent when the mice are challenged with a high-fat diet which also causes a much more pronounced diurnal variation in gene expression. Nocturnin knockout mice only show a transient and small reduction in body fat whilst UCP1 gene expression is unaffected (Kawai et al., 2010). Taken together, these findings suggest that the animal is able to compensate for the absence of nocturnin by other mechanisms related to the control of circadian rhythms, thus emphasizing the complexity of these processes.

A majority of mammals including humans can show marked seasonal variations in body weight which also appear to be driven by changes in photoperiod (Heldmaier and Steinlechner, 1981). One hormone which is highly responsive to changes in day length is prolactin, a hormone which regulates a wide range of biological processes essential for the development of mammals including gonadal function and reproduction, mammary development and lactation, adrenal and pancreatic endocrine secretion and metabolism (Goffin et al., 2002). It acts through a specific prolactin 
receptor (PRLR) which has at least three isoforms expressed in both BAT (Symonds et al., 1998) and white adipose tissue (Ling et al., 2000) and has been implicated in the regulation of adipose tissue mass (Freemark et al., 2001). Two recent genome-wide association studies have identified a variant (rs4712652) adjacent to the prolactin gene which is associated with excess body weight (Meyre et al., 2009; Nilsson et al., 2011). Furthermore, as may be expected for a gene which is closely involved in reproductive function, this relationship is gender specific with the risk A allele of rs4712652 being strongly correlated with body mass index and fat mass in males but not females (Nilsson et al., 2011).

Previous clinical studies have demonstrated that correction of hyperprolactinaemia in humans acts to normalize body weight, although it has a much greater effect on reducing excess body weight in males compared to females (Greenman et al., 1998). However, obese females with a normal prolactin profile do benefit, at least in the short term, from a reduction in prolactin secretion achieved following administration of the dopamine $\mathrm{D}_{2}$ receptor agonist bromocriptine (Kok et al., 2006). This intervention promotes both lipolysis and heat production, adaptations which may also be indicative of enhanced BAT thermogenesis. The latter may be important as BAT is retained into adult life in humans when the main supraclavicular depots is accompanied by additional deposits in the paraspinal and suprarenal regions (Cypess et al., 2009; van Marken Lichtenbelt et al., 2009; Virtanen et al., 2009).

Currently, very little is known about the primary factors which control UCP1 function within BAT depots in humans, although photoperiod is one potential factor (Au-Yong et al., 2009) which could be mediated through changes in prolactin. The extent to which photoperiod, as opposed to ambient temperature, is a primary regulator of BAT function remains uncertain. Photoperiod can determine BAT activity irrespective of ambient temperature, an effect which is enhanced in the cold (Klingenspor et al., 1989; Wiesinger et al., 1989) suggesting different long- and short-term regulation of BAT activity. It should also be noted that during normal development in the sheep, an increase in PRLR abundance is a vital stage in fetal BAT development (Symonds et al., 1998, 2011). Moreover, in the newborn sheep, direct stimulation of the PRLR promotes BAT thermogenesis (Pearce et al., 2005). These results have been confirmed in a mouse PRLR knockout model which demonstrated that in mice lacking PRLR, BAT growth and development was severely impaired, as was the expression of a number of brown adipogenic genes including UCP1 (Viengchareun et al., 2008). Prolactin, acting through the PRLR, may, therefore, have a primary role in regulating fetal BAT development and its thermogenic activity, a relationship which may extend into adulthood. Importantly this system is responsive to a range of environmental stimuli and not only dietary challenges.

\section{EPIGENETIC REGULATION OF ADIPOSE TISSUE FUNCTION}

We are just starting to appreciate epigenetic regulation and its potential regulation of the long-term determination of energy homeostasis. Although there is one study in which large changes in methyl status of the diet can shift coat color of agouti-mice (Waterland and Jirtle, 2003), this has very little effect on the fraction of normal weight mice and the number of overweight animals. Any accompanying effects on energy balance are likely to be very modest and do not readily support a strong role for epigenetics in regulating adipose tissue function (Symonds, 2009). Obesity induced by consumption of a high-fat sucrose diet in 8-week-old rats also fails to induce any detectable effects on the methylation status of genes related to energy homeostasis within the liver (Lomba et al., 2010). It is becoming apparent that simply looking at methylation status of individual genes in one tissue (Lillycrop and Burdge, 2011) is much less informative than more robust global assessments (e.g., using the HELP assay) in tissues that have a defined role in phenotypic outcome such as the pancreas (Thompson et al., 2010). They can be accompanied by changes in enhanced enrichment of $\mathrm{H} 3 \mathrm{~K} 27 \mathrm{me} 3$ that could be critical in determining the age-related decline in pancreatic function and thus onset of type 2 diabetes (Sandovici et al., 2011). These findings emphasize the point that simply measuring fractional methylation of a gene only provides very limited in-sight into the pathways involved. Furthermore, there is not a close relationship between changes in methylation status and genes expression during development, at least in the rodent liver (Waterland et al., 2009).

To date, the most persuasive rodent model for a role of an epigenetic presetting of energy metabolism comes from a knockout of the histone H3k9-specific demethylase Jhdma2a which results in increased body weight after 8 weeks of age (Inagaki et al., 2009). This effect appears to be mediated by a reduction in the amount of BAT making the animals more susceptible to cold induced hypothermia and less able to oxidize fat primarily due to a disruption of $\beta$-adrenergic stimulation (Tateishi et al., 2009). Moreover, effects on metabolism become most apparent during the end of the night phase when activity levels in knockout animals are less variable (Inagaki et al., 2009). Interestingly, Jhdm2a can also directly regulate PPAR $\alpha$ and UCP1 expression, such that the obesogenic effects of knocking out this histone demethylase are specific to BAT and muscle and not accompanied by increased food intake or changes in metabolic hormone profiles (Tateishi et al., 2009). A potential role for Jhdm 2 a in early development of BAT remains to be established although knockout animals are infertile and exhibit impaired spermatogenesis (Okada et al., 2007, 2010).

\section{EXPERIMENTAL MODELS OF THE OBESITY RELATED Fto GENE AND ITS POTENTIAL CONTRIBUTION TO FAT MASS}

Another factor, linked to nucleic acid stability, which plays a role in obesity, comes with the discovery of the Fto gene. Fto is one highly topical example of the substantial phenotypic differences obtained within mouse models which either knockout (Fischer et al., 2009; Gao et al., 2010) or increase copy number (Church et al., 2010). The obesity-associated Fto gene is particularly intriguing as it is much more closely linked to body mass index than any other single nucleotide polymorphism identified (Frayling et al., 2007), although this relationship may be age dependent and not linked to detectable differences in energy balance (Hakanen et al., 2009). Moreover, Fto encodes a 2-oxoglutarate-dependent nucleic acid demethylase which is involved in the production of succinate, formaldehyde and carbon dioxide (Gerken et al., 2007). Inactivation of Fto reduces body weight from 2 days after birth which persists for the duration of the study and is, therefore, indicative of very early growth failure. The latter would be predicted to be accompanied with reduced fat stores (Fischer et al., 2009). This 
sustained long-term outcome does not appear to be due to any difference in food intake and whether it was caused by increased energy expenditure as opposed to reduced energy stores has yet to be detailed. Interestingly this finding has not been supported by a more recent study using a comparable model (Gao et al., 2010). Moreover, the site of Fto knockout, i.e., global or confined to the central nervous system, appears to have a marked gender specificity in effects of postnatal growth (Fischer et al., 2009; Gao et al., 2010). Consequently, accompanying differences in activity with gender may be one explanation as to why Fto knockout mice exhibit a substantial reduction in night-time, but not day-time activity.

The opposite effect of ablating the Fto gene has also been examined very recently by increasing tissue copy number (Church et al., 2010). One surprising aspect of this study is that the relative abundance of Fto within the hypothalamus was similar to all other tissues (Church et al., 2010) rather than being two- to fourfold higher as in other publications across a number of species (Gerken et al., 2007; Sebert et al., 2010). Furthermore, the greatest increase in relative expression was within skeletal muscle (Church et al., 2010), the only other tissue established to date to show an agerelated increase in expression between birth and adulthood, at least in sheep (Sebert et al., 2010). Such differences in gene expression do not appear to be translated into protein, as Fto protein abundance in all tissues studied to date appears to be completely unresponsive to a range of dietary challenges (Gao et al., 2010). From a developmental view-point, it is noteworthy that mRNA abundance of Fto in the placental is positively correlated with fetal weight in the sheep (Sebert et al., 2010) further supporting a role for Fto in early growth (Bassols et al., 2010).

Increased Fto copy number was, perhaps surprisingly, accompanied with increased food intake (Church et al., 2010), a response which is opposite to that seen with increased hypothalamic gene expression in large mammals (Sebert et al., 2010). One explanation for the change in food intake is that Fto copy number was accompanied by leptin resistance, exacerbating the obese phenotype (Church et al., 2010). This contrasts with the effect of deleting the Fto gene in which no interaction between plasma leptin and Fto gene expression in the hypothalamus was seen (Gerken et al., 2007). It is apparent that with increased Fto copy number females are less responsive to being fed a high-fat diet which reduces food intake but promotes fat deposition (Church et al., 2010). The extent to which this may relate to differences in Fto gene expression between specific tissues or hypothalamic sensitivity which could also contribute to greater activity in females remains to be explored. As summarized in Figure 2 the Fto gene has multiple roles for which the primary signals and outcomes remain to be further defined.

In conclusion, the current obesity epidemic reflects multiple interactions between our lifestyle and inherited genetic background. Clearly, the type of diet consumed and a lack of physical activity will promote obesity especially in a constant thermoneutral environment. Nonetheless, this does not replicate epidemiological observations. Both the causes and the consequences of obesity are dependent on multiple factors which need to be understood in much more detail to enable effective prevention and treatment. This will depend on our ability to unravel the interactions between gene and environment during critical windows of susceptibility that includes early life. Our review aims to encourage a greater multidisciplinary, multispecies, approach and the need to develop more relevant and thus complex models of obesity.

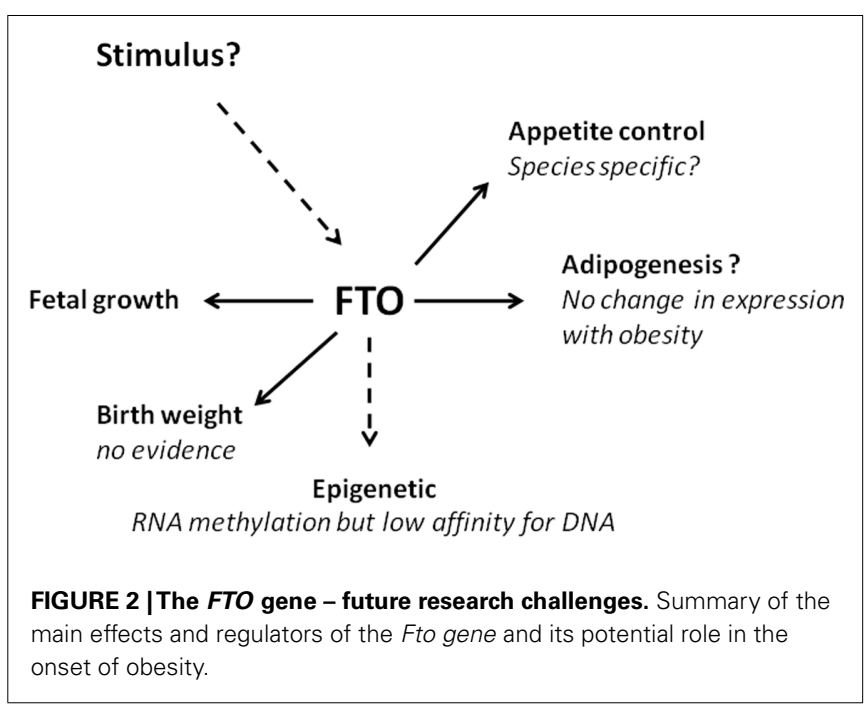

\section{REFERENCES}

Adrie, C., Azoulay, E., Francais, A., Clec'h, C., Darques, L., Schwebel, C., Nakache, D., Jamali, S., GoldgranToledano, D., Garrouste-Orgeas, M., and Timsit, J. F. (2007). Influence of gender on the outcome of severe sepsis: a reappraisal. Chest 132, 1786-1793.

Ainge, H., Thompson, C., Ozanne, S. E., and Rooney, K. B. (2010). A systematic review on animal models of maternal high fat feeding and offspring glycaemic control. Int. J. Obes. (Lond.) 35, 325-335

Au-Yong, I. T., Thorn, N., Ganatra, R., Perkins, A. C., and Symonds,
M. E. (2009). Brown adipose tissue and seasonal variation in humans. Diabetes 58, 2583-2587.

Ballard, P. L. (1983). Mode of action of glucocorticoids on lung maturation. Curr. Probl. Clin. Biochem. 13, 35-46.

Bassols, J., Prats-Puig, A., VazquezRuiz, M., Garcia-Gonzalez, M. M., Martinez-Pascual, M., Avelli, P., Martinez-Martinez, R., Fabrega, R., Colomer-Virosta, C., SorianoRodriguez, P., Diaz, M., De Zegher, F., Ibanez, L., and Lopez-Bermejo, A. (2010). Placental FTO expression relates to fetal growth. Int. J. Obes. (Lond.) 34, 1365-1370.
Bauer, F., Elbers, C. C., Adan, R. A., Loos, R. J., Onland-Moret, N. C., Grobbee, D. E., Van Vliet-Ostaptchouk, J. V., Wijmenga, C., and Van Der Schouw, Y. T. (2009). Obesity genes identified in genome-wide association studies are associated with adiposity measures and potentially with nutrientspecific food preference. Am. J. Clin. Nutr. 90, 951-959.

Bayol, S. A., Farrington, S. J., and Stickland, N. C. (2007). A maternal 'junk food' diet in pregnancy and lactation promotes an exacerbated taste for 'junk food' and a greater propensity for obesity in rat offspring. $\mathrm{Br}$. $J$. Nutr. 98, 843-851.
Bayol, S. A., Simbi, B. H., Bertrand, J. A., and Stickland, N. C. (2008). Offspring from mothers fed a 'junk food' diet in pregnancy and lactation exhibit exacerbated adiposity that is more pronounced in females. J. Physiol. (Lond.) 586, 3219-3230.

Bleich, S. N., Ku, R., and Wang, Y. C. (2011). Relative contribution of energy intake and energy expenditure to childhood obesity: a review of the literature and directions for future research. Int. J. Obes. (Lond.) $35,1-15$.

Bray, G. A., Nielsen, S. J., and Popkin, B. M. (2004). Consumption of 
high-fructose corn syrup in beverages may play a role in the epidemic of obesity. Am. J. Clin. Nutr. 79, 537-543.

Budge, H., Bispham, J., Dandrea, J., Evans, E., Heasman, L., Ingleton, P. M., Sullivan, C., Wilson, V., Stephenson, T., and Symonds, M. E. (2000). Effect of maternal nutrition on brown adipose tissue and its prolactin receptor status in the fetal lamb. Pediatr. Res. 47, 781-786.

Budge, H., and Symonds, M. E. (2006). "Fetal and neonatal nutrition lipid and carbohydrate requirements and adaptations to altered supply at birth," in Textbook of Perinatal Medicine, eds H. Winn and P. D. Gluckman (Boca Raton: CRC Press), 1007-1016.

Cannon, B., and Nedergaard, J. (2004). Brown adipose tissue: function and significance. Phys. Rev. 84, 277-359.

Cannon, B., and Nedergaard, J. (2008). Developmental biology: neither fat nor flesh. Nature 454, 947-948.

Catalano, P. M. (2007). Increasing maternal obesity and weight gain during pregnancy: the obstetric problems of plentitude. Obstet. Gynecol. 110, 743-744.

Charreire, H., Kesse-Guyot, E., Bertrais, S., Simon, C., Chaix, B., Weber, C., Touvier, M., Galan, P., Hercberg, S., and Oppert, J. M. (2011). Associations between dietary patterns, physical activity (leisure-time and occupational) and television viewing in middle-aged French adults. $\mathrm{Br}$. J. Nutr. 1-8.

Church, C., Moir, L., McMurray, F., Girard, C., Banks, G. T., Teboul, L., Wells, S., Bruning, J. C., Nolan, P. M., Ashcroft, F. M., and Cox, R. D. (2010). Overexpression of Fto leads to increased food intake and results in obesity. Nat. Genet. 42, 1086-1092.

Clarke, L., Buss, D. S., Juniper, D. S., Lomax, M. A., and Symonds, M. E. (1997). Adipose tissue development during early postnatal life in ewe-reared lambs. Exp. Physiol. 82, 1015-1017.

Cortright, R. N., Chandler, M. P., Lemon, P. W., and Dicarlo, S. E. (1997). Daily exercise reduces fat, protein and body mass in male but not female rats. Physiol. Behav. 62, 105-111.

Cypess, A. M., and Kahn, C. R. (2010a). Brown fat as a therapy for obesity and diabetes. Curr. Opin. Endocrinol. Diabetes Obes. 17, 143-149.

Cypess, A. M., and Kahn, C. R. (2010b). The role and importance of brown adipose tissue in energy homeostasis. Curr. Opin. Pediatr. 22, 478-484.
Cypess, A. M., Lehman, S., Williams, G., Tal, I., Rodman, D., Goldfine, A. B. Kuo, F. C., Palmer, E. L., Tseng, Y. H., Doria, A., Kolodny, G. M., and Kahn, C. R. (2009). Identification and importance of brown adipose tissue in adult humans. N. Engl. J. Med. 360, 1509-1517.

den Hoed, M., Ekelund, U., Brage, S., Grontved, A., Zhao, J. H., Sharp, S. J., Ong, K. K., Wareham, N. J., and Loos, R. J. (2010). Genetic susceptibility to obesity and related traits in childhood and adolescence: influence of loci identified by genomewide association studies. Diabetes 59, 2980-2988.

Fischer, J., Koch, L., Emmerling, C., Vierkotten, J., Peters, T., Bruning, J. C., and Ruther, U. (2009). Inactivation of the Fto gene protects from obesity. Nature 458, 894-898.

Flegal, K. M., Carroll, M. D., Ogden, C. L., and Curtin, L. R. (2010). Prevalence and trends in obesity among US adults, 1999-2008. J. Am. Diet. Assoc. 303, 235-241.

Fonken, L. K., Workman, J. L., Walton, J. C., Weil, Z. M., Morris, J. S., Haim, A., and Nelson, R. J. (2010). Light at night increases body mass by shifting the time of food intake. Proc. Natl. Acad. Sci. U.S.A. 107, 18664-18669.

Frayling, T. M., Timpson, N. J., Weedon, M. N., Zeggini, E., Freathy, R. M., Lindgren, C. M., Perry, J. R., Elliott, K. S., Lango, H., Rayner, N. W., Shields, B., Harries, L. W., Barrett, J. C., Ellard, S., Groves, C. J., Knight, B., Patch, A. M., Ness, A. R., Ebrahim, S., Lawlor, D. A., Ring, S. M., BenShlomo, Y., Jarvelin, M. R., Sovio, U., Bennett, A. J., Melzer, D., Ferrucci, L., Loos, R. J., Barroso, I., Wareham, N. J., Karpe, F., Owen, K. R., Cardon, L. R., Walker, M., Hitman, G. A., Palmer, C. N., Doney, A. S., Morris, A. D., Smith, G. D., Hattersley, A. T., and McCarthy, M. I. (2007). A common variant in the FTO gene is associated with body mass index and predisposes to childhood and adult obesity. Science 316, 889-894.

Freemark, M., Fleenor, D., Driscoll, P., Binart, N., and Kelly, P. A. (2001). Body weight and fat deposition in prolactin receptor-deficient mice. Endocrinology 142, 532-537.

Gao, X., Shin, Y. H., Li, M., Wang, F., Tong, Q., and Zhang, P. (2010). The fat mass and obesity associated gene FTO functions in the brain to regulate postnatal growth in mice. PLoS ONE 5, e14005. doi: 10.1371/journal.pone.0014005

Garriguet, D. (2007). Canadians' eating habits. Health Rep. 18, 17-32.
Gaziano, J. M. (2010). Fifth phase of the epidemiologic transition: the age of obesity and inactivity. J. Am. Diet. Assoc. 303, 275-276.

Gerken, T., Girard, C. A., Tung, Y. C. Webby, C. J., Saudek, V., Hewitson, K. S., Yeo, G. S., McDonough, M. A., Cunliffe, S., McNeill, L. A., Galvanovskis, J., Rorsman, P., Robins, P., Prieur, X., Coll, A. P., Ma, M., Jovanovic, Z., Farooqi, I. S., Sedgwick, B., Barroso, I., Lindahl, T., Ponting, C. P., Ashcroft, F. M., O'rahilly, S., and Schofield, C. J. (2007). The obesity-associated FTO gene encodes a 2-oxoglutaratedependent nucleic acid demethylase. Science 318, 1469-1472.

Gimble, J. M., and Floyd, Z. E. (2009). Fat circadian biology. J. Appl. Physiol. 107, 1629-1637.

Goffin, V., Binart, N., Touraine, P., and Kelly, P. A. (2002). Prolactin: the new biology of an old hormone. Annu. Rev. Physiol. 64, 47-67.

Green, C. B., Douris, N., Kojima, S. Strayer, C. A., Fogerty, J., Lourim, D., Keller, S. R., and Besharse, J. C. (2007). Loss of Nocturnin, a circadian deadenylase, confers resistance to hepatic steatosis and diet-induced obesity. Proc. Natl. Acad. Sci. U.S.A. 104, 9888-9893.

Greenman, Y., Tordjman, K., and Stern, N. (1998). Increased body weight associated with prolactin secreting pituitary adenomas: weight loss with normalization of prolactin levels. Clin. Endocrinol. (Oxf.) 48, 547-553.

Hakanen, M., Raitakari, O. T., Lehtimaki, T., Peltonen, N., Pahkala, K., Sillanmaki, L., Lagstrom, H., Viikari, J., Simell, O., and Ronnemaa, T. (2009). FTO genotype is associated with body mass index after the age of seven years but not with energy intake or leisure-time physical activity. J. Clin. Endocrinol. Metab. 94, 1281-1287.

Hansen, J., Sato, M., Kharecha, P., Russell, G., Lea, D. W., and Siddall, M. (2007). Climate change and trace gases. Philos. Transact. A Math. Phys. Eng. Sci. 365, 1925-1954.

Harden, A., Brunton, G., Fletcher, A., and Oakley, A. (2009). Teenage pregnancy and social disadvantage: systematic review integrating controlled trials and qualitative studies. BMJ 339, b4254. doi: 10.1136/bmj.b4254

Heldmaier, G., and Steinlechner, S. (1981). Seasonal control of energy requirments for thermogulation in the Djungarian hamster (Phodopus sungorus) living in natural photoperiod. J. Comp. Physiol. 142, 429-437.
Hulshof, K. F., Brussaard, J. H., Kruizinga, A. G., Telman, J., and Lowik, M. R. (2003). Socioeconomic status, dietary intake and 10 y trends: the Dutch National Food Consumption Survey. Eur. J. Clin. Nutr. 57, 128-137.

Inagaki, T., Tachibana, M., Magoori, K., Kudo, H., Tanaka, T., Okamura, M., Naito, M., Kodama, T., Shinkai, Y., and Sakai, J. (2009). Obesity and metabolic syndrome in histone demethylase JHDM2adeficient mice. Genes Cells 14, 991-1001.

Johnson, F., Mavroggiani, A., Ucci, M., Vidal-Puig, A., and Wardle, J. (2011). Could increased time spent in a thermal comfort zone contribute to population increases in obesity? Obes. Rev. doi: 10.1111/j.1467789x.2010.0085.x. [Epub ahead of print].

Jones, H. N., Woollett, L. A., Barbour, N., Prasad, P. D., Powell, T. L., and Jansson, T. (2009). High-fat diet before and during pregnancy causes marked up-regulation of placental nutrient transport and fetal overgrowth in C57/BL6 mice. FASEB J. 23, 271-278.

Juneau, C. E., and Potvin, L. (2010). Trends in leisure-, transport-, and work-related physical activity in Canada 1994-2005. Prev. Med. 51 384-386.

Kawai, M., Green, C. B., LeckaCzernik, B., Douris, N., Gilbert, M. R., Kojima, S., Ackert-Bicknell, C., Garg, N., Horowitz, M. C., Adamo, M. L., Clemmons, D. R., and Rosen, C. J. (2010). A circadianregulated gene, Nocturnin, promotes adipogenesis by stimulating PPAR-gamma nuclear translocation. Proc. Natl. Acad. Sci. U.S.A. 107, 10508-10513.

Kearney, J. (2010). Food consumption trends and drivers. Philos. Trans. R. Soc. Lond., B, Biol. Sci. 365, 2793-2807.

Keith, S. W., Redden, D. T., Katzmarzyk, P. T., Boggiano, M. M., Hanlon, E. C., Benca, R. M., Ruden, D., Pietrobelli, A., Barger, J. L., Fontaine, K. R., Wang, C., Aronne, L. J., Wright, S. M., Baskin, M., Dhurandhar, N. V., Lijoi, M. C., Grilo, C. M., Deluca, M., Westfall, A. O., and Allison, D. B. (2006). Putative contributors to the secular increase in obesity: exploring the roads less traveled. Int. J. Obes. (Lond.) 30, 1585-1594.

Kelly, Y. J., and Watt, R. G. (2005). Breast-feeding initiation and exclusive duration at 6 months by social class - results from the Millennium Cohort Study. Public Health Nutr. 8, 417-421. 
Khan, I. Y., Taylor, P. D., Dekou, V., Seed, P. T., Lakasing, L., Graham, D., Dominiczak, A. F., Hanson, M. A., and Poston, L. (2003). Genderlinked hypertension in offspring of lard-fed pregnant rats. Hypertension $41,168-175$.

Kirk, S. L., Samuelsson, A. M., Argenton, M., Dhonye, H., Kalamatianos, T., Poston, L., Taylor, P. D., and Coen, C. W. (2009). Maternal obesity induced by diet in rats permanently influences central processes regulating food intake in offspring. PLoS ONE 4, e5870. doi: 10.1371/journal. pone. 0005870

Klimentidis, Y. C., Beasley, T. M., Lin, H. Y., Murati, G., Glass, G. E., Guyton, M., Newton, W., Jorgensen, M., Heymsfield, S. B., Kemnitz, J., Fairbanks, L., and Allison, D. B. (2011). Canaries in the coal mine: a cross-species analysis of the plurality of obesity epidemics. Proc. Biol. Sci. 278, 1626-1632.

Klingenspor, M., Klaus, S., Wiesinger, H., and Heldmaier, G. (1989). Short photoperiod and cold activate brown fat lipoprotein lipase in the Djungarian hamster. Am. J. Physiol. Regul. Integr. Comp. Physiol. 257, R1123-R1127.

Knudsen, V. K., Orozova-Bekkevold, I. M., Mikkelsen, T. B., Wolff, S., and Olsen, S. F. (2008). Major dietary patterns in pregnancy and fetal growth. Eur. J. Clin. Nutr. 62, 463-470.

Kok, P., Roelfsema, F., Frolich, M., Van Pelt, J., Stokkel, M. P., Meinders, A. E., and Pijl, H. (2006). Activation of dopamine D2 receptors simultaneously ameliorates various metabolic features of obese women. Am. J. Physiol. Endocrinol. Metab. 291, E1038-E1043.

Lee, P., Greenfield, J. R., Ho, K. K., and Fulham, M. J. (2010). A critical appraisal of the prevalence and metabolic significance of brown adipose tissue in adult humans. Am. J. Physiol. Endocrinol. Metab. 299, E601-E606.

Li, S., Zhao, J. H., Luan, J., Luben, R. N., Rodwell, S. A., Khaw, K. T., Ong, K. K., Wareham, N. J., and Loos, R. J. (2010). Cumulative effects and predictive value of common obesity-susceptibility variants identified by genome-wide association studies. Am. J. Clin. Nutr. 91, 184-190.

Liefbroer, A. C. (2009). Changes in family size intentions across young adulthood: a life-course perspective. Eur. J. Popul. 25, 363-386.

Lillycrop, K. A., and Burdge, G. C. (2011). Epigenetic changes in early life and future risk of obesity. Int. J. Obes. (Lond.). 35, 72-83.

Lindgren, C. M., Heid, I. M., Randall, J. C., Lamina, C., Steinthorsdottir, V., Qi, L., Speliotes, E. K., Thorleifsson, G., Willer, C. J., Herrera, B. M., Jackson, A. U., Lim, N., Scheet, P., Soranzo, N., Amin, N., Aulchenko, Y. S., Chambers, J. C., Drong, A., Luan, J., Lyon, H. N., Rivadeneira, F., Sanna, S., Timpson, N. J., Zillikens, M. C., Zhao, J. H., Almgren, P., Bandinelli, S., Bennett, A. J., Bergman, R. N., Bonnycastle, L. L., Bumpstead, S. J., Chanock, S. J., Cherkas, L., Chines, P., Coin, L., Cooper, C., Crawford, G., Doering, A., Dominiczak, A., Doney, A. S., Ebrahim, S., Elliott, P., Erdos, M. R., Estrada, K., Ferrucci, L., Fischer, G., Forouhi, N. G., Gieger, C., Grallert, H., Groves, C. J., Grundy, S., Guiducci, C., Hadley, D., Hamsten, A., Havulinna, A. S., Hofman, A., Holle, R., Holloway, J. W., Illig, T., Isomaa, B., Jacobs, L. C., Jameson, K., Jousilahti, P., Karpe, F., Kuusisto, J., Laitinen, J., Lathrop, G. M., Lawlor, D. A., Mangino, M., McArdle, W. L., Meitinger, T., Morken, M. A., Morris, A. P., Munroe, P., Narisu, N., Nordstrom, A., Nordstrom, P., Oostra, B. A., Palmer, C. N., Payne, F., Peden, J. F., Prokopenko, I., Renstrom, F., Ruokonen, A., Salomaa, V., Sandhu, M. S., Scott, L. J., Scuteri, A., Silander, K., Song, K., Yuan, X., Stringham, H. M., Swift, A. J., Tuomi, T., Uda, M., Vollenweider, P., Waeber, G., Wallace, C., Walters, G. B., Weedon, M. N., Wellcome Trust Case Control Consortium, Witteman, J. C., Zhang, C., Zhang, W., Caulfield, M. J., Collins, F. S., Davey Smith, G., Day, I. N., Franks, P. W., Hattersley, A. T., $\mathrm{Hu}$, F. B., Jarvelin, M. R., Kong, A., Kooner, J. S., Laakso, M., Lakatta, E., Mooser, V., Morris, A. D., Peltonen, L., Samani, N. J., Spector, T. D., Strachan, D. P., Tanaka, T., Tuomilehto, J., Uitterlinden, A. G., van Duijn, C. M., Wareham, N. J., Watkins, H., Procardis Consortia, Waterworth, D. M., Boehnke, M., Deloukas, P., Groop, L., Hunter, D. J., Thorsteinsdottir, U., Schlessinger, D., Wichmann, H. E., Frayling, T. M., Abecasis, G. R., Hirschhorn, J. N., Loos, R. J., Stefansson, K., Mohlke, K. L., Barroso, I., McCarthy, M. I., and Giant Consortium. (2009). Genome-wide association scan meta-analysis identifies three Loci influencing adiposity and fat distribution. PLoS Genet. 5, e1000508. doi: 10.1371/annotation/b6e8f9f6-24964a40-b0e3-e1d1390c1928

Ling, C., Hellgren, G., Gebre-Medhin, M., Dillner, K., Wennbo, H., Carlsson, B., and Billig, H. (2000). Prolactin (PRL) receptor gene expression in mouse adipose tissue: increases during lactation and in PRL-transgenic mice. Endocrinology 141, 3564-3572.

Lomba, A., Milagro, F. I., Garcia-Diaz, D. F., Marti, A., Campion, J., and Martinez, J. A. (2010). Obesity induced by a pair-fed high fat sucrose diet: methylation and expression pattern of genes related to energy homeostasis. Lipids Health Dis. 9, 60 .

Martin, B., Ji, S., Maudsley, S., and Mattson, M. P. (2010). "Control" laboratory rodents are metabolically morbid: why it matters. Proc. Natl. Acad. Sci. U.S.A. 107, 6127-6133.

Masi, C. M., Hawkley, L. C., Piotrowski, Z. H., and Pickett, K. E. (2007). Neighborhood economic disadvantage, violent crime, group density, and pregnancy outcomes in a diverse, urban population. Soc. Sci. Med. 65, 2440-2457.

McAllister, E. J., Dhurandhar, N. V., Keith, S. W., Aronne, L. J., Barger, J., Baskin, M., Benca, R. M., Biggio, J., Boggiano, M. M., Eisenmann, J. C., Elobeid, M., Fontaine, K. R., Gluckman, P., Hanlon, E. C., Katzmarzyk, P., Pietrobelli, A., Redden, D. T., Ruden, D. M., Wang, C., Waterland, R. A., Wright, S. M., and Allison, D. B. (2009). Ten putative contributors to the obesity epidemic. Crit. Rev. Food Sci. Nutr. 49, 868-913.

McCurdy, C. E., Bishop, J. M., Williams, S. M., Grayson, B. E., Smith, M. S., Friedman, J. E., and Grove, K. L. (2009). Maternal high-fat diet triggers lipotoxicity in the fetal livers of nonhuman primates. J. Clin. Invest. 119, 323-335.

McMillen, I. C., and Robinson, J. S. (2005). Developmental origins of the metabolic syndrome: prediction, plasticity, and programming. Physiol. Rev. 85, 571-633.

Meyerholz, D. K., Stoltz, D. A., Pezzulo, A. A., and Welsh, M. J. (2010). Pathology of gastrointestinal organs in a porcine model of cystic fibrosis. Am. J. Pathol. 176, 1377-1389.

Meyre, D., Delplanque, J., Chevre, J. C., Lecoeur, C., Lobbens, S., Gallina, S., Durand, E., Vatin, V., Degraeve, F., Proenca, C., Gaget, S., Korner, A., Kovacs, P., Kiess, W., Tichet, J., Marre, M., Hartikainen, A. L.,
Horber, F., Potoczna, N., Hercberg, S., Levy-Marchal, C., Pattou, F., Heude, B., Tauber, M., McCarthy, M. I., Blakemore, A. I., Montpetit, A., Polychronakos, C., Weill, J., Coin, L. J., Asher, J., Elliott, P., Jarvelin, M. R., Visvikis-Siest, S., Balkau, B., Sladek, R., Balding, D., Walley, A., Dina, C., and Froguel, P. (2009). Genome-wide association study for early-onset and morbid adult obesity identifies three new risk loci in European populations. Nat. Genet. 41, 157-159.

Ng, S. F., Lin, R. C., Laybutt, D. R., Barres, R., Owens, J. A., and Morris, M. J. (2010). Chronic high-fat diet in fathers programs beta-cell dysfunction in female rat offspring. Nature 467, 963-966.

Nilsson, L., Olsson, A. H., Isomaa, B., Groop, L., Billig, H., and Ling, C. (2011). A common variant near the PRL gene is associated with increased adiposity in males. Mol. Genet. Metab. 102, 78-81.

Okada, Y., Scott, G., Ray, M. K., Mishina, Y., and Zhang, Y. (2007). Histone demethylase JHDM2A is critical for Tnpl and Prml transcription and spermatogenesis. Nature 450, 119-123.

Okada, Y., Tateishi, K., and Zhang, Y. (2010). Histone demethylase JHDM2A is involved in male infertility and obesity. J. Androl. 31, 75-78.

Olson, E. B. Jr. (1979). Role of glucocorticoids in lung maturation. J. Anim. Sci. 49, 225-238.

Pearce, S., Budge, H., Mostyn, A., Genever, E., Webb, R., Ingleton, P., Walker, A. M., Symonds, M. E., and Stephenson, T. (2005). Prolactin, the prolactin receptor and uncoupling protein abundance and function in adipose tissue during development in young sheep. J. Endocrinol. 184, 351-359.

Pearce, S., Casteilla, L., Gualillo, O., Symonds, M. E., and Stephenson, T. (2003). Differential effects of age and gender on the postnatal responsiveness of brown adipose tissue to prolactin administration in rats. Exp. Physiol. 88.4, 527-531.

Pettinger, C., Holdsworth, M., and Gerber, M. (2008). 'All under one roof?' differences in food availability and shopping patterns in Southern France and Central England. Eur. J. Public. Health 18, 109-114.

Popkin, B. M., Haines, P. S., and Reidy, K. C. (1989). Food consumption trends of US women: patterns and determinants between 1977 and 1985. Am. J. Clin. Nutr. 49, 1307-1319. 
Power, G. (1989). Biology of temperature: the mammalian fetus. J. Dev. Physiol. 12, 295-304.

Puttonen, S., Harma, M., and Hublin, C. (2010). Shift work and cardiovascular disease-pathways from circadian stress to morbidity. Scand. J. Work Environ. Health 36, 96-108.

Ramsden, E. (2009). The urban animal: population density and social pathology in rodents and humans. Bull. World Health Organ. 87, 82.

Regitz-Zagrosek, V., Lehmkuhl, E., and Weickert, M. O. (2006). Gender differences in the metabolic syndrome and their role for cardiovascular disease. Clin. Res. Cardiol. 95, 136-147.

Reilly, J. J., and Kelly, J. (2010). Longterm impact of overweight and obesity in childhood and adolescence on morbidity and premature mortality in adulthood: systematic review. Int. J. Obes. (Lond.). doi: 10.1038/ijo.2010.222. [Epub ahead of print].

Rogers, C. S., Abraham, W. M., Brogden, K. A., Engelhardt, J. F., Fisher, J. T., McCray, P. B. Jr., McLennan, G., Meyerholz, D. K., Namati, E., Ostedgaard, L. S., Prather, R. S., Sabater, J. R., Stoltz, D. A., Zabner, J., and Welsh, M. J. (2008). The porcine lung as a potential model for cystic fibrosis. Am. J. Physiol. Lung Cell Mol. Physiol. 295, L240-L263.

Rothwell, N. J., and Stock, M. J. (1979). A role for brown adipose tissue in diet-induced thermogenesis. Nature 281, 31-35.

Rothwell, N. J., and Stock, M. J. (1983). Luxuskonsumption, dietinduced thermogenesis and brown fat: the case in favour. Clin. Sci. (Lond.) 64, 19-23.

Rothwell, N. J., Stock, M. J., Warwick, B. P., and Winter, P. D. (1983). Diurnal variations in circulating hormone levels and brown adipose tissue activity in "cafeteria"-fed rats. Comp. Biochem. Physiol. A Comp. Physiol. 75, 461-465.

Rousset, S., Alves-Guerra, M.-C., Ouadghiri-Bencherif, S., Kozak, L. P., Miroux, B., Richard, D., Bouillaud, F., Ricquier, D., and Cassard-Doulcier, A.-M. (2003). UCP2 is expressed in the female mice reproductive tract whereas UCP1 is not. J. Biol. Chem. 278, 45843-45847.

Samuelsson, A. M., Matthews, P. A., Argenton, M., Christie, M. R., McConnell, J. M., Jansen, E. H., Piersma, A. H., Ozanne, S. E., Twinn, D. F., Remacle, C., Rowlerson, A., Poston, L., and Taylor, P. D. (2008). Diet-induced obesity in female mice leads to offspring hyperphagia, adiposity, hypertension, and insulin resistance: a novel murine model of developmental programming. Hypertension 51, 383-392.

Sandovici, I., Smith, N. H., Nitert, M. D., Ackers-Johnson, M., UribeLewis, S., Ito, Y., Jones, R. H., Marquez, V. E., Cairns, W., Tadayyon, M., O’neill, L. P., Murrell, A., Ling, C., Constancia, M., and Ozanne, S. E. (2011). Maternal diet and aging alter the epigenetic control of a promoter-enhancer interaction at the Hnf4a gene in rat pancreatic islets. Proc. Natl. Acad. Sci. U.S.A. 108, 5449-5454.

Scheen, A. J. (2010). Suspension of the commercialization of sibutramine and rosiglitazone in Europe. Rev. Med. Liege 65, 574-579.

Schrauwen, P., and Westerterp, K. R. (2000). The role of high-fat diets and physical activity in the regulation of body weight. Br. J. Nutr. 84, 417-427.

Sebert, S. P., Hyatt, M. A., Chan, L. L., Yiallourides, M., Fainberg, H. P., Patel, N., Sharkey, D., Stephenson, T., Rhind, S. M., Bell, R. C., Budge, H., Gardner, D. S., and Symonds, M. E. (2010). Influence of prenatal nutrition and obesity on tissue specific fat mass and obesity-associated (FTO) gene expression. Reproduction 139, 265-274.

Sewell, M. F., Huston-Presley, L., Super, D. M., and Catalano, P. (2006). Increased neonatal fat mass, not lean body mass, is associated with maternal obesity. Am. J. Obstet. Gynecol. 195, 1100-1103.

Shaw, L. J., Shaw, R. E., Merz, C. N., Brindis, R. G., Klein, L. W., Nallamothu, B., Douglas, P. S., Krone, R. J., McKay, C. R., Block, P. C., Hewitt, K., Weintraub, W. S., and Peterson, E. D. (2008). Impact of ethnicity and gender differences on angiographic coronary artery disease prevalence and in-hospital mortality in the American College of CardiologyNational Cardiovascular Data Registry. Circulation 117, 1787-1801.

Skafida, V. (2009). The relative importance of social class and maternal education for breast-feeding initiation. Public Health Nutr. 12, 2285-2292.

Slyper, A. H. (2004). The pediatric obesity epidemic: causes and controversies. J. Clin. Endocrinol. Metab. 89, 2540-2547.

Stahl, A., Vohmann, C., Richter, A., Heseker, H., and Mensink, G. B. (2009). Changes in food and nutrient intake of 6- to 17-year-old Germans between the 1980s and 2006 . Public Health Nutr. 12, 1912-1923.

Stefanidis, A., Verty, A. N., Allen, A. M., Owens, N. C., Cowley, M. A., and Oldfield, B. J. (2009). The role of thermogenesis in antipsychotic drug-induced weight gain. Obesity (Silver Spring) 17, 16-24.

Svensson, P. A., Jernas, M., Sjoholm, K., Hoffmann, J. M., Nilsson, B. E., Hansson, M., and Carlsson, L. M. (2011). Gene expression in human brown adipose tissue. Int. J. Mol. Med. 27, 227-232.

Symonds, M. E. (2007). Integration of physiological and molecular mechanisms of the developmental origins of adult disease: new concepts and insights. Proc. Nutr. Soc. 66, 442-450.

Symonds, M. E. (2009). Nutrition and its contribution to obesity and diabetes: a life-course approach to disease prevention? Proc. Nutr. Soc. 68, 71-77.

Symonds, M. E., and Budge, H. (2009). Nutritional models of the developmental programming of adult health and disease. Proc. Nutr. Soc. 68 173-178.

Symonds, M. E., Budge, H., Perkins, A. C., and Lomax, M. A. (2011). Adipose tissue development impact of the early life environment. Prog. Biophys. Mol. Biol. doi: 10.1016/j.pbiomolbio.2010.11.008. [Epub ahead of print].

Symonds, M. E., Mostyn, A., Pearce, S., Budge, H., and Stephenson, T. (2003). Endocrine and nutritional regulation of fetal adipose tissue development. J. Endocrinol. 179, 293-299.

Symonds, M. E., Phillips, I. D., Anthony, R. V., Owens, J. A., and McMillen, I. C. (1998). Prolactin receptor gene expression and foetal adipose tissue. J. Neuroendocrinol. 10, 885-890.

Symonds, M. E., Sebert, S. P., and Budge, H. (2010). Dangers of dieting: what advice should be given to obese expectant mothers? Expert Rev. Obstet. Gynecol. 5, 39-47.

Symonds, M. E., Sebert, S. P., Hyatt, M. A., and Budge, H. (2009). Nutritional programming of the metabolic syndrome. Nat. Rev. Endocrinol. 5, 604-610.

Szosland, D. (2011). Shift work and metabolic syndrome, diabetes mellitus and ischaemic heart disease. Int J. Occup. Med. Environ. Health 23, 287-291.

Tateishi, K., Okada, Y., Kallin, E. M., and Zhang, Y. (2009). Role of Jhdm2a in regulating metabolic gene expression and obesity resistance. Nature 458, 757-761.

Thompson, R. F., Fazzari, M. J., Niu, H., Barzilai, N., Simmons, R. A., and Greally, J. M. (2010). Experimental intrauterine growth restriction induces alterations in DNA methylation and gene expression in pancreatic islets of rats. J. Biol. Chem. 285, 15111-15118.
Tromp, M., Ravelli, A. C., Reitsma, J. B., Bonsel, G. J., and Mol, B. W. (2011). Increasing maternal age at first pregnancy planning: health outcomes and associated costs. J. Epidemiol. Community Health. doi: 10.1136/jech.2009.095422 [Epub ahead of print].

van Marken Lichtenbelt, W. D., Vanhommerig, J. W., Smulders, N. M., Drossaerts, J. M., Kemerink, G. J., Bouvy, N. D., Schrauwen, P., and Teule, G. J. (2009). Cold-activated brown adipose tissue in healthy men. N. Engl. J. Med. 360, 1500-1508.

Viengchareun, S., Servel, N., Feve, B., Freemark, M., Lombes, M., and Binart, N. (2008). Prolactin receptor signaling is essential for perinatal brown adipocyte function: a role for insulin-like growth factor-2. PLoS ONE 3, e1535. doi: 10.1371/journal.pone.0001535

Vijgen, G. H., Bouvy, N. D., Teule, G. J., Brans, B., Schrauwen, P., and van Marken Lichtenbelt, W. D. (2011). Brown adipose tissue in morbidly obese subjects. PLoS ONE 6, e17247. doi: 10.1371/journal.pone.0017247

Virtanen, K. A., Lidell, M. E., Orava, J., Heglind, M., Westergren, R., Niemi, T., Taittonen, M., Laine, J., Savisto, N. J., Enerback, S., and Nuutila, P. (2009). Functional brown adipose tissue in healthy adults. N. Engl. J. Med. 360, 1518-1525.

Walker, G. (2006). Climate change: the tipping point of the iceberg. Nature 441, 802-805.

Wang, J., Ma, H., Tong, C., Zhang, H., Lawlis, G. B., Li, Y., Zang, M., Ren, J., Nijland, M. J., Ford, S. P. Nathanielsz, P. W., and Li, J. (2010) Overnutrition and maternal obesity in sheep pregnancy alter the JNK-IRS-1 signaling cascades and cardiac function in the fetal heart. FASEB J. 24, 2066-2076.

Wang, Y., Osterbur, D. L., Megaw, P. L., Tosini, G., Fukuhara, C., Green, C. B., and Besharse, J. C. (2001). Rhythmic expression of Nocturnin mRNA in multiple tissues of the mouse. BMC Dev. Biol. 1, 9. doi: 10.1186/1471-213X-1-9

Waterland, R. A., and Jirtle, R. L. (2003). Transposable elements: targets for early nutritional effects on epigenetic gene regulation. Mol. Cell. Biol. 23, 5293-5300.

Waterland, R. A., Kellermayer, R., Rached, M. T., Tatevian, N., Gomes, M. V., Zhang, J., Zhang, L., Chakravarty, A., Zhu, W., Laritsky, E., Zhang, W., Wang, X., and Shen, L. (2009). Epigenomic profiling indicates a role for DNA methylation in early postnatal liver development. Hum. Mol. Genet. 18, 3026-3038. 
Wells, J. C., Hallal, P. C., Reichert, F. F., Menezes, A. M., Araujo, C. L., and Victora, C. G. (2008). Sleep patterns and television viewing in relation to obesity and blood pressure: evidence from an adolescent Brazilian birth cohort. Int. J. Obes. (Lond.) 32, 1042-1049.

Wiesinger, H., Heldmaier, G., and Buchberger, A. (1989). Effect of photoperiod and acclimation temperature on nonshivering thermogenesis and GDP-binding of brown fat mitochondria in the Djungarian hamster Phodopus s. sungorus. Pflugers Arch. 413, 667-672.

Zvonic, S., Ptitsyn, A. A., Conrad, S. A., Scott, L. K., Floyd, Z. E., Kilroy, G., Wu, X., Goh, B. C., Mynatt, R. L., and Gimble, J. M. (2006). Characterization of peripheral circadian clocks in adipose tissues. Diabetes $55,962-970$.

Conflict of Interest Statement: The authors declare that the research was conducted in the absence of any commercial or financial relationships that could be construed as a potential conflict of interest.

Received: 08 February 2011; accepted: 12 May 2011; published online: 31 May 2011.

Citation: Symonds ME, Sebert $S$ and Budge $H$ (2011) The obesity epidemic: from the environment to epigenetics - not simply a response to dietary manipulation in a thermoneutral environment. Front. Gene. 2:24. doi: 10.3389/fgene.2011.00024

This article was submitted to Frontiers in Epigenomics, a specialty of Frontiers in Genetics.

Copyright $\odot 2011$ Symonds, Sebert and Budge. This is an open-access article subject to a non-exclusive license between the authors and Frontiers Media SA, which permits use, distribution and reproduction in other forums, provided the original authors and source are credited and other Frontiers conditions are complied with. 